\title{
木質接着パネル構法における立体建物の水平抵抗機構に関する研究 \\ A STUDY ON LATERAL RESISTANCE MECHANISM \\ OF THREE-DIMENSION BUILDING BY WOODEN PANELS CONSTRUCTION
}

\author{
梶川久光*1, 野口弘行*2 \\ Hisamitsu KAJIKA WA and Hiroyuki NOGUCHI
}

\begin{abstract}
The purpose of this study is to elucidate the lateral resistance mechanism of wooden space building and to evaluate the method of calculation for wooden structure, so two direction lateral loading tests of full scale building with two-storey is carried out. Size of the test models is $6 \mathrm{P} \times 8 \mathrm{P} \times$ two-storey $(5,460 \times 7,280$ $\times 5,606$ ), and four type models (setbacktype,none-eccentricity,uniaxial-eccentricity,biaxial-eccentricity) were carried out. We weighed the experiment values against the calculated values by the. finite element method analysis, and deepened our consideration of lateral behavior, especially two direction load, three-dimension effect, torsional stiffnes, of wooden building .
\end{abstract}

Keywords: Full Scale Test, Two Direction Load, Wooden Panels Construction, Finite Element Method,Three-dimension Effect, Torsional Stiffness

実大建物実験、，2 方向加力、木質接着パネル構法、有限要素法、立体効果、ねじり剛性

\section{1 研究目的}

現在に至るまで、木質構造において耐力壁のせん断実験及び実 大建物の水平加力実験が多数行われ、水平力に対する抵抗機構の解 明が行われてきた。しかし、単体としての耐力壁、床構面の水平力 に対する力学的性状については明らかになりつつあるが、立体建 物としての水平抵抗機構に関しての研究はまだまだ不十分である。 また、木質構造における構造設計においても仕様規定的で簡便な ものが主流となっており構造計算と現実建物の力学的性状との整 合性がよく見えてないのが現実である。そこで、本研究において は、木質接着パネル構法による立体建物実験 4 ()5)6)、耐力壁単体実 験 ${ }^{\left.7{ }^{11}\right)}$ 及び有限要素法解析を行い、木質立体建物の水平抵抗機構 の解明及び、木質構造計算方法の評価を研究目的に置き次の項目 について考察及び検討を行う。「立体建物におけるせん断耐力及び 变形の評価」建物の水平せん断耐力を正確に評価するに際してて耐 力壁の荷重・変位関係の足し合わせ方法の提案及び立体建物の性状 との比較検討を行う。「立体効果」立体建物の水平せん断耐力を評 価する場合に、立体実験（3 次元）のデータで評価する場合と単体 耐力壁実験（2 次元）のデータで評価する場合の違いを立体効果と し、考察及び検討を行う。「建物に斜めに水平力を受ける場合 $(2$ 方向加力) の検討」斜めより水平力を受ける木質立体建物の力学的 性状について考察・検討を行う。また、斜めより水平力を受ける場
合に、X 方向・ $\mathrm{Y}$ 方向の足し合わせによりその性状を再現できる のかどうかを明確にしその範囲を示す。

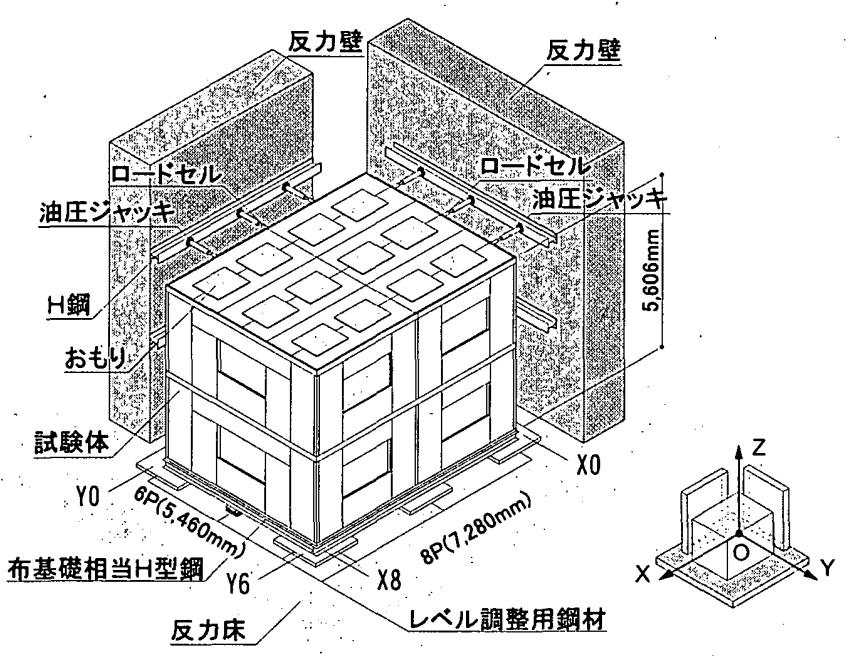

図 1 実験概要図
*1ミサワホーム侏構造技術グループ 工博

*2 明治大学理工学部建築学科・教授・工博
Structural Design Group, Misawa Home- Co., Ltd., Dr. Eng.

Prof., Dept. of Architecture School of Science Technology, Meiji Univ., Dr. Eng. 


\section{2 実大 2 層立体建物における水平加力実験 \\ 2.1 試験体等 \\ 2.1.1 座標軸及ひ通り名}

座標軸、通り名及び原点は図 1 に示す通りである。

\subsection{2 試験体}

試験体を図 2 に示す。試験体は木質接着複合パネル ${ }^{\sharp 1} に よ$ り構成される $6 \mathrm{P} \times 8 \mathrm{P} \times$ 建物高さ $(5,460 \mathrm{~mm} \times 7,280 \mathrm{~mm} \times$ $5,606 \mathrm{~mm} ; 1 \mathrm{P}=910 \mathrm{~mm})$ の 2 層箱形建物である。試験体の種類は、 各壁面を空型開口としたセットバック形状のもの、各壁面を空型 開口とした無偏心のもの、X8 通りの壁面をドア型開ロとし、その 他の壁面を空型開口とした片偏心 (偏心率:Rex $=0.00, R e y=0.38$ ) のもの、X8 通り及び Y6 通りの壁面をドア型開口とし、その他の 壁面を空型開口とした両偏心 (偏心率:Rex $=0.18, \operatorname{Rey}=0.41$ )のも のの 4 種類があり、それぞれフェーズ・1(セットバック)、フェー ズ・2(無偏心)、フェーズ・3(片偏心)、フェーズ・4 (両偏心) と設 定した。また、床構面には固定荷重、積載荷重として想定したおも りを図 1 に示すように設置した。なお、偏心率は「3. 単体耐力壁 せん断実験」の結果より初期剛性を用いて算出した。各壁面の構 造形状を表 1 に示す。又、緊結ボルト及びアンカーボルトの納ま りを表 2 に示す。

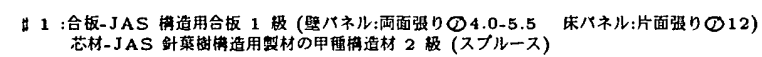
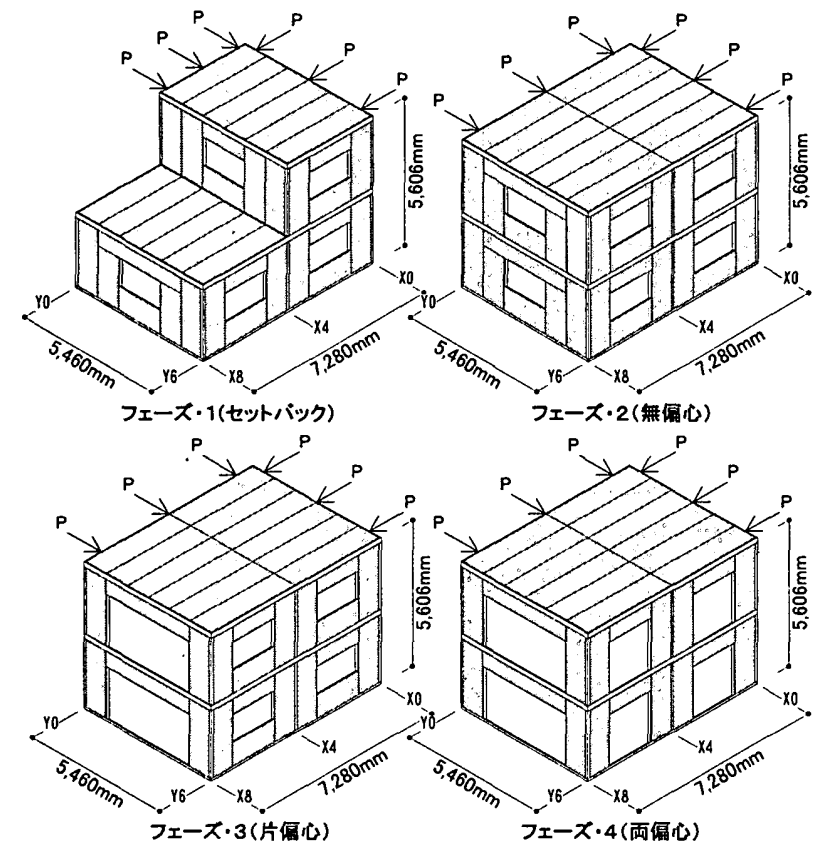

図 2 試験体図

\section{2 実験方法}

\subsection{1 加力方法}

加力は図 1 に示す反力壁に水平に並列して設置した油圧ジャッ キを用い、反力床の上に設置した試験体の $\mathrm{R}$ 階床を押し引きして 行った。加力の種類は、 1 方向加力 (等価の 3 点加力)、 2 方向加力 (各方向それぞれ等価の 3 点加力) の 2 種類とし、 1 方向加力は $\mathrm{X}$ 方向加力、Y 方向加力を行った。加力は変位量が最大となる壁面の 層間変形角で制御し (比例限度内、フェーズ・4の 2 方向加力のみ 破壊に至るまで加力)、表 3 に示す加力スケジュールに従い行った。
表 1 各壁面の構造形状

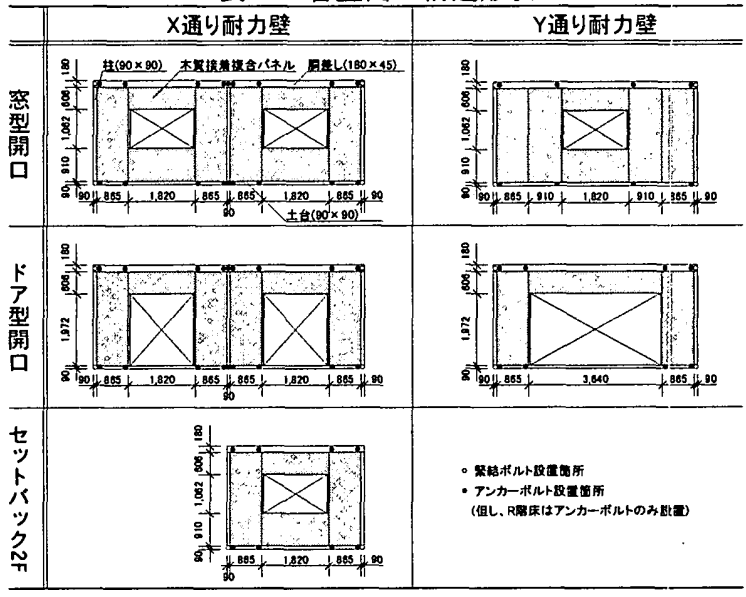

表 2 各接合部の納まり

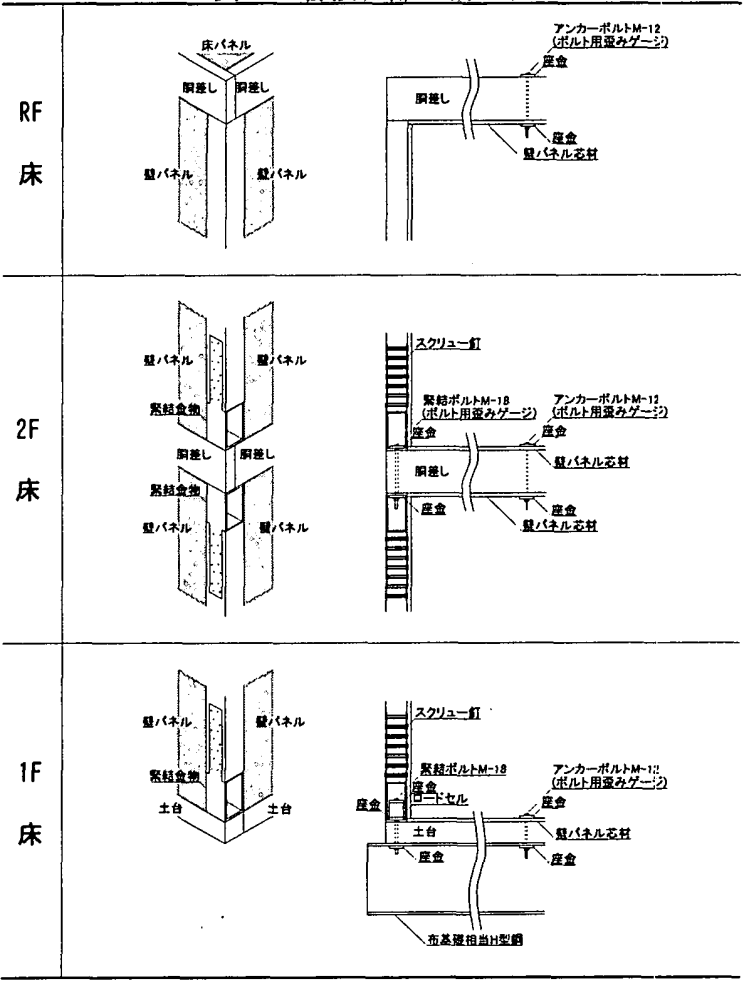

表 3 加力方向と加力スケジュール

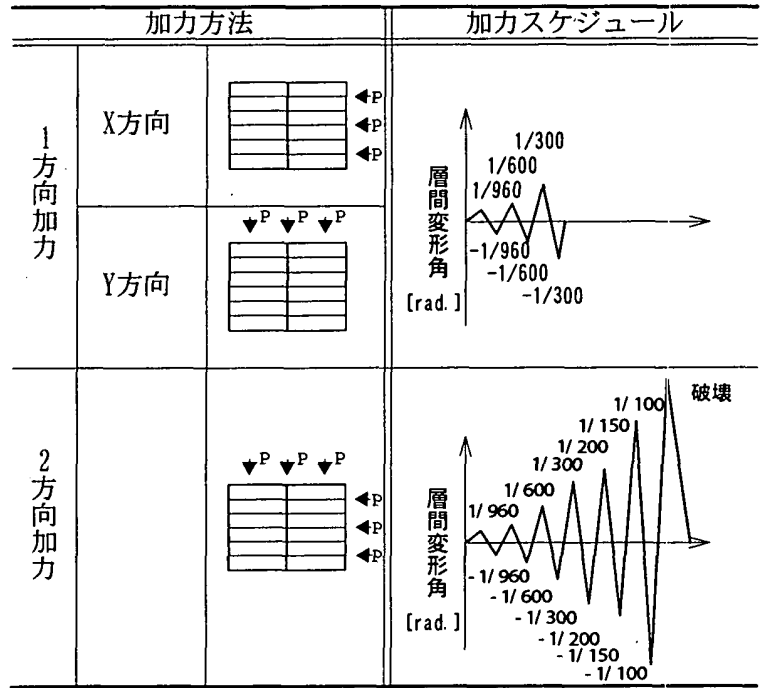




\subsection{2 測定方法}

測定機器の配置を図 3 に示す。水平荷重は、 $\mathrm{H}$ 鋼と油圧ジャッ キの間に取り付けた $[200 \mathrm{kN}$ 用ロードセル（2 箇所：図 1 参照)」 によって測定した。緊結ボルトの引抜力は、「 $100 \mathrm{kN}$ 用ロードセル (8 箇所)」を設置して測定した。変位量は、各点に変位計 (148 箇 所）を設置して測定した。面材・枠材のせん断歪みは、「歪みゲー ジ (476 箅所)」によって測定した。アンカーボルトの引抜力は、 「ボルト用歪みゲージ（80 箇所）」を用い、「土台」と「布基礎相当 $\mathrm{H}$ 型鋼」との「アンカーボルトの引抜力」を測定した。(※計測機 器は全て東京測器研究所ものを使用)
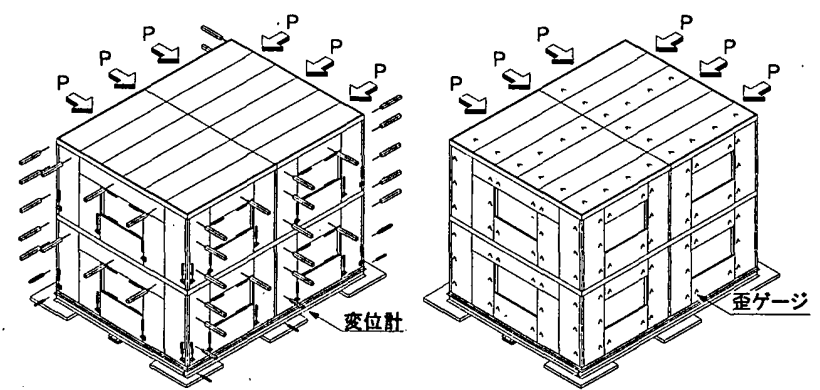

図 3 測定機器図例 $($ フェーズ・2)

\section{3 実験結果}

\subsection{1 荷重-層間变形角の関係}

図 4 にフェーズ・4、2 方向加力試験の水平荷重-層間変形角関 係を、表 4 に剛性の低い方の耐力壁 (表中の網掛け部分) の層間変 形角が $1 / 300[\mathrm{rad}:]$ 時における各試験体の水平荷重と各壁面の層 間変形角の関係を示す。なお、フェーズ・4の 2 方向加力におけ る最大耐力は X 方向 $Y$ 方向それぞれ $146.75 \mathrm{kN}$ ( $45^{\circ}$ 方向では $207.54 \mathrm{kN}$ ) であった。

表 4 荷重と層間変形角との関係

\begin{tabular}{|c|c|c|c|c|c|c|c|c|c|c|c|}
\hline & 方 & & 水平倚需 $|\mathrm{kN}|$ & & 2層 & rad. & & & 触 & rad. & \\
\hline & \multirow{4}{*}{ 1方向加力 } & \multirow{2}{*}{ X方向 } & \multirow{2}{*}{48.8} & $\mathrm{X0}$ & 0.00002 & $\times 4$ & 0.00003 & & 0.00001 & $\times 87$ & 0.000 \\
\hline$x$ & & & & YO & 0.00333 & 16 & 0.00318 & 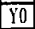 & 0.00121 & $Y 6$ & 0.00137 \\
\hline 1 & & \multirow{2}{*}{ 方向 } & \multirow{2}{*}{ 77. 1} & $\mathrm{X} 0$ & 0.00301 & X4 & 0.00256 & $\times 0$ & 0.00333 & $\times 8$ & 0.00330 \\
\hline ズ & & & & 10 & 0.00012 & Y6 & \begin{tabular}{|l|}
0.00001 \\
\end{tabular} & 10 & -0.00045 & Y6 & 0.00029 \\
\hline \multirow[b]{2}{*}{1} & \multirow{2}{*}{\multicolumn{2}{|c|}{ 方向柇 }} & \multirow{2}{*}{65.1} & $\times 0$ & 0.00236 & $X 4$ & 0.00194 & $\times 0$ & 0.00276 & $\times 8$ & 0.00248 \\
\hline & & & & $\mathrm{YO}$ & 0.00330 & 96 & 0.00333 & 10 & 0.00088 & Y6 & 0.00186 \\
\hline ᄀ & \multirow{4}{*}{ 1方向加力 } & \multirow{2}{*}{ X方向 } & \multirow{2}{*}{107.7} & \begin{tabular}{|l|} 
\\
\end{tabular} & 0.00008 & $\times 8$ & 0.0 & \begin{tabular}{|l|}
$\times 0$ \\
\end{tabular} & -0.00004 & $\times 8$ & 0.00009 \\
\hline$I$ & & & & $\mathrm{Y}$ & 0.00333 & $\mathrm{Y}_{6}$ & 0.00318 & $Y^{\prime} 0$ & 0.00315 & $\mathrm{Y}_{6}$ & 0.00300 \\
\hline 1 & & \multirow{2}{*}{ Y方向 } & \multirow{2}{*}{94.2} & $X_{0}$ & 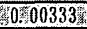 & 88 & 0.00326 & $\times 0$ & 0.00312 & $\times 8$ & 0.00317 \\
\hline$x^{2}$ & & & & 10 & -0.00003 & 16 & -0.00003 & YO & 0.00004 & Y6 & 0.00002 \\
\hline \multirow[b]{2}{*}{2} & \multirow{2}{*}{\multicolumn{2}{|c|}{ 2方向力 }} & \multirow{2}{*}{106.6} & $X_{0}$ & 0.00330 & \begin{tabular}{|l|}
$X 8$ \\
\end{tabular} & 0.00333 & $\times 0$ & 0.00312 & $\times 8$ & 0.00314 \\
\hline & & & & Yo & 0.00268 & \begin{tabular}{|l|} 
Y6 \\
\end{tabular} & 0.00268 & Y0 & 0.00261 & $\begin{array}{ll}6 \\
\end{array}$ & 0.00255 \\
\hline$\overline{7}$ & \multirow{4}{*}{ 1方向加力 } & \multirow{2}{*}{ X方向 } & \multirow{2}{*}{ 109. 6} & $\mathrm{X0}$ & 0.00009 & $\times 8$ & -0.00004 & $\times 0$ & 0.00001 & $\times 8$ & 0.00001 \\
\hline$x$ & & & & 10 & 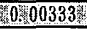 & $Y 6$ & 0.00319 & 10 & 0.00305 & 96 & 0.00309 \\
\hline .1 & & \multirow{2}{*}{ Y方向 } & & \begin{tabular}{|l|l}
$X_{0}$ \\
\end{tabular} & 0.00198 & X8 & 90800333 & \begin{tabular}{|l|}
$\times 0$ \\
\end{tabular} & 0.00188 & $\times 8$ & 0.00289 \\
\hline$\pi$ & & & & 10 & 0.00030 & Y6 & -0.00045 & Y0 & 0.00029 & 46 & -0.00037 \\
\hline $0^{\circ}$ & \multirow{2}{*}{\multicolumn{2}{|c|}{ 2方向加力 }} & \multirow{2}{*}{51.5} & $X_{0}$ & 0.00199 & $\mathrm{X8}$ & 0.00333 & \begin{tabular}{|l|}
$\mathrm{X0}$ \\
\end{tabular} & 0.00188 & $\mathrm{X8}$ & 0.00309 \\
\hline 3 & & & & Yo & $0.00156^{\circ}$ & Y6 & 0.00072 & 10 & 0.00149 & $y_{6}$ & 0.00068 \\
\hline 7 & \multirow{4}{*}{ 加力 } & \multirow{2}{*}{ X方向 } & \multirow{2}{*}{85.1} & \begin{tabular}{|l|} 
\\
\end{tabular} & 0.00017 & \begin{tabular}{|l|}
$\mathrm{X8}$ \\
\end{tabular} & -0.00045 & \begin{tabular}{|l|}
$\mathrm{X} 0$ \\
\end{tabular} & 0.00013 & $\times 8$ & -0.00065 \\
\hline$x$ & & & & Y0 & 0.00286 & $Y_{6}$ & 0.00333 & 10 & 0.00267 & $Y 6$ & 0.00309 \\
\hline 1 & & \multirow{2}{*}{ Y方向 } & \multirow{2}{*}{ 43. 4} & \begin{tabular}{|l|}
$\mathrm{X0}$ \\
\end{tabular} & 0.00191 & X8 & 0.00333 & $\mathrm{X0}$ & 0.00175 & 88 & 0.00290 \\
\hline$\pi$ & & & & Y0 & 0.00027 & Y6 & -0.00059 & Y0 & 0.00027 & 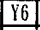 & -0.00051 \\
\hline & \multirow{2}{*}{\multicolumn{2}{|c|}{ 2方向加力 }} & \multirow{2}{*}{48.} & $\times 0$ & 0.00204 & \begin{tabular}{|l|}
$\times 8$ \\
\end{tabular} & 0.00333 & $\mathrm{X} 0$ & 0.00187 & \begin{tabular}{|l|} 
\\
\end{tabular} & 0.00297 \\
\hline 4 & & & & 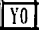 & 0.00161 & Y6 & 0.00102 & YO & 0.00158 & Y6 & 0.00077 \\
\hline
\end{tabular}

\subsection{2 破壊性状}

表 5 にフェーズ・4の 2 方向加力試験を行った時の破壊性状を示 す。表中の(1)〜 (4)は図 4 に示す箇所における破壊性状を示す。破
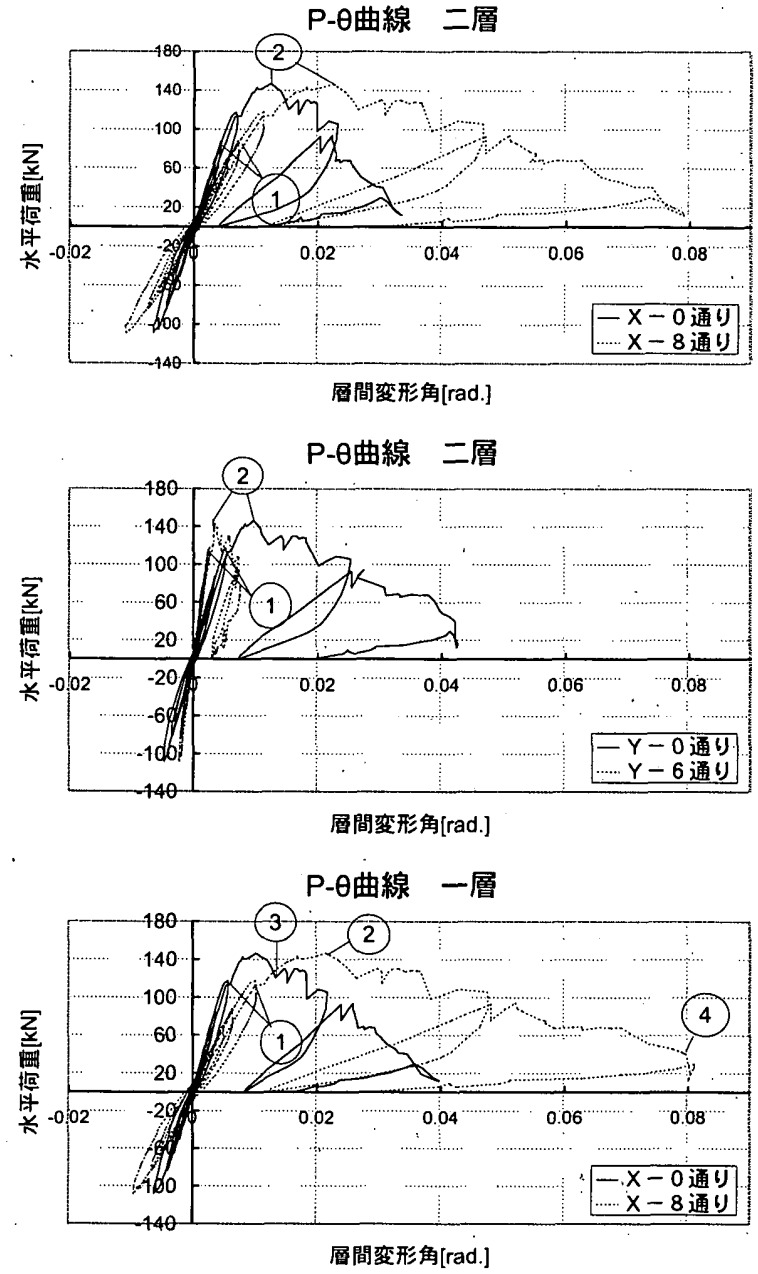

P- $\theta$ 曲線 一層

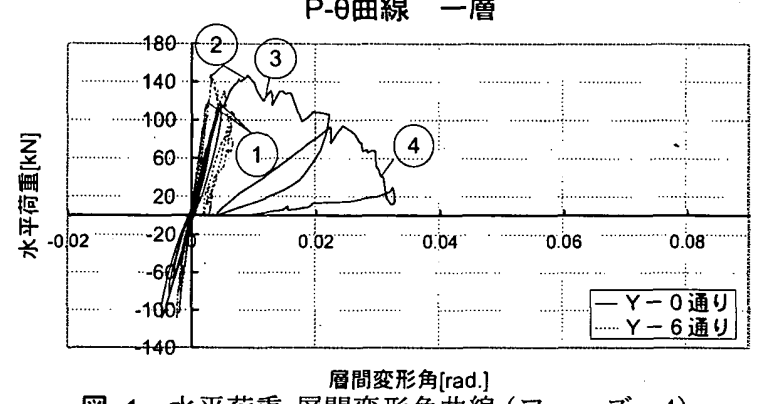

図 4 水平荷重-層間変形角曲線 $($ フェーズ・4)

壊は X8 通りの壁構面がローリングシヤー破壊 (せん断力が働く方 向が単板の繊維方向と直角をなすときに、直角方向の繊維をころが すような形で起こる破罗) ${ }^{1) p p 259-261}$ を起こし、最大荷重後、原 点の脚部において柱の引き抜けや土台へのめり込みが起こった。最 大耐力を決定する破壊性状としては、合板のローリングシャー破 壊が挙げられる。

表 5 破壊性状

\begin{tabular}{|c|c|}
\hline & 破壊性状 \\
\hline (1) & 耐力壁の小壁 (垂壁・腰壁) の接合部が開く。 \\
\hline (2) & $\mathrm{X} 8$ 通り壁パネルの合板の面外座屈及びローリングシヤー破壊 (Pmax) \\
\hline (3) & (X0,Y0) の脚部においてホールダウン金物の釘が破壇し柱が引き拔けた。 \\
\hline (4) & $\mathrm{X} 8$ 通り側の柱が破睃し $2 \mathrm{~F}$ 林の胴差しが折れ曲がった。 \\
\hline
\end{tabular}




\subsection{3 引き抜き力}

表 6 に各試験体の脚部引き抜き力 (同位置に緊結ボルト、アン カーボルトが数本ある場合はその合計) を示す。水平荷重は X 方 向加力及びY方向加力の場合は $40 \mathrm{kN} 、 \mathrm{XY}$ 方向加力の場合は各方 向において 40kN である。

表 6 各試験の脚部引き抜き力 $[\mathrm{kN}]$

\begin{tabular}{|c|c|c|c|c|}
\hline & 位置 & X方向加力 & Y方向加力 & XY方向加力 \\
\hline \multirow{4}{*}{ フェーズ・1 } & $\overline{\mathrm{X} 0, \mathrm{YO}}$ & 10.60 & 13.73 & 21.40 \\
\hline & $\mathrm{X0,Y6}$ & 5.42 & -4.67 & -0.50 \\
\hline & $\mathrm{X} 8, \mathrm{YO}$ & -2.82 & -0.80 & -2.60 \\
\hline & $\mathrm{X} 8, \mathrm{Y} 6$ & -2.29 & 0.47 & -1.08 \\
\hline \multirow{4}{*}{ フェーズ・2 } & $\mathrm{X} 0, \mathrm{YO}$ & 7.62 & 11.70 & 18.30 \\
\hline & $\mathrm{X} 0, \mathrm{Y} 6$ & 4.76 & -4.81 & -1.98 \\
\hline & $\mathrm{X} 8, \mathrm{Y0}$ & -3.08 & -0.38 & -2.80 \\
\hline & $\mathrm{X} 8, \mathrm{Y} 6$ & -3.09 & 2.29 & -2.48 \\
\hline \multirow{4}{*}{$R$} & $\mathrm{X} 0, \mathrm{YO}$ & 6.63 & 16.06 & 21.57 \\
\hline & $\mathrm{X} 0, \mathrm{Y} 6$ & 5.09 & -5.54 & -2.99 \\
\hline & $\mathrm{X} 8, \mathrm{YO}$ & -2.68 & -0.10 & -2.04 \\
\hline & $\mathrm{X} 8, \mathrm{Y} 6$ & -2.61 & 2.25 & -1.10 \\
\hline \multirow{4}{*}{ フェーズ・4 } & $\mathrm{X} 0, \mathrm{YO}$ & 7.45 & 16.45 & 24.02 \\
\hline & $\mathrm{X} 0, \mathrm{Y} 6$ & 4.41 & -5.02 & -2.49 \\
\hline & $\mathrm{X} 8, \mathrm{Y0}$ & -2.53 & 1.35 & -1.44 \\
\hline & $\mathrm{X8}, \mathrm{Y} 6$ & -3.62 & 3.08 & -0.79 \\
\hline
\end{tabular}

\section{3 単体耐力壁せん断実験}

\section{1 実験概要}

本実験は耐力壁の力学的性状を解明する為及び実大建物と単体 壁の相関性を検証する為に独立法人森林総合研究所実験棟におい $\tau$ 計 17 体 $^{7)}$ 、明治大学理工学部構造物試験棟において計 10 体 ${ }^{11)}$ の合計 27 体行われた。加力方法としては正負交番繰り返し載荷と 単調載荷の 2 種類とし、壁面の見掛けのせん断変形角により制御 し、破壊に至るまで行った。測定は「変位計・歪みゲージ・ロード セル」を用い、各点を測定した。

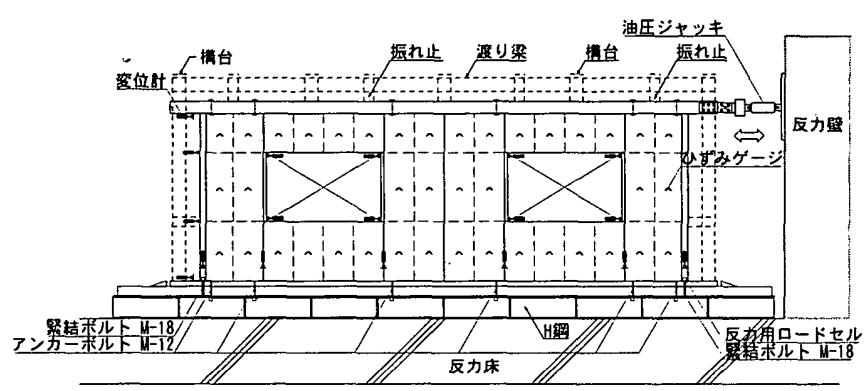

図 5 実験概要図

\subsection{1 実験結果}

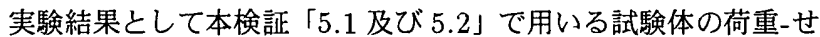
ん断変形角曲線 (包絡線) を図 6 に示す。

\section{4 有限要素法解析}

\section{1 解析モデル}

解析モデルを図 7 に示す。解析モデルは実大実験の試験体形状及 び試験体寸法を基本とし床構面のせん断弾性係数を变化させた有限 要素法解析による立体解析モデルである。パラメータとして、壁長 を $6 \mathrm{P}$ 及び $8 \mathrm{P}$ の 2 種類、偏心率として無偏心、片偏心及び両偏心 の 3 種類、床構面のせん断弾性係数を 49.03[ $\mathrm{N} / \mathrm{mm}^{2}$ ] (在来軸組構 法相当)、147.10[N/ $\left.\mathrm{mm}^{2}\right]$ (枠組壁工法相当)、392.27[N/ $\left.\mathrm{mm}^{2}\right]($ 木

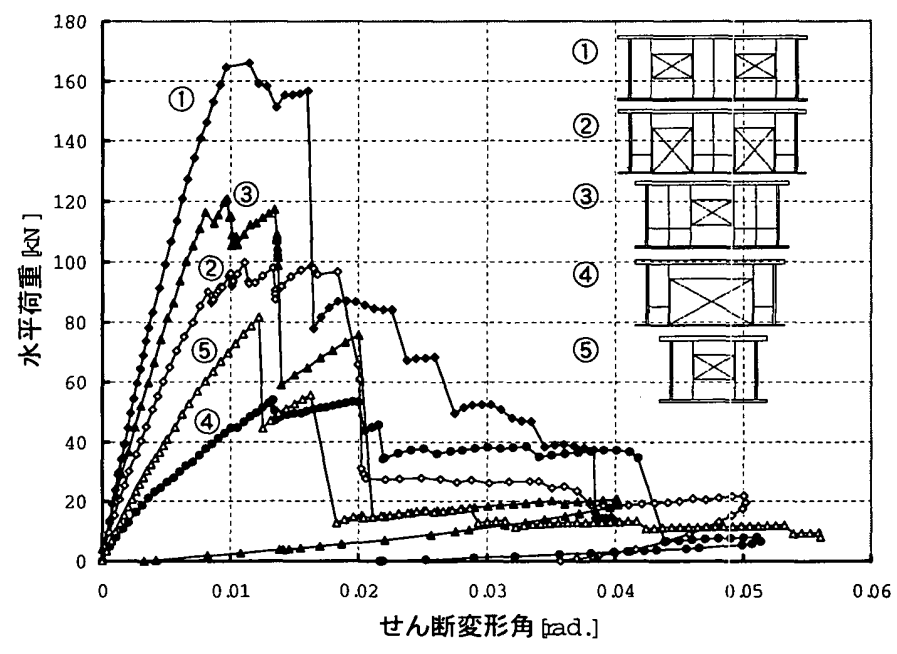

図 6 荷重一せん断変形角曲線

質接着パネル構法相当)、1177.80[N/ $\left.\mathrm{mm}^{2}\right]$ (木質接着パネル構法相 当の 3 倍) の 4 種類、加力方法として X 方向加力、Y 方向加力及 び 2 方向同時加力の 3 種類、脚部のバネ剛性として緊結ボルトの バネ剛性を $18.6[\mathrm{kN} / \mathrm{mm}](\mathrm{M}-18$ 相当)、9.3[kN/mm](M-18 相当 の $1 / 2) 、 1.9[\mathrm{kN} / \mathrm{mm}](\mathrm{M}-18$ 相当の $1 / 10)$ の 3 種類を設定した。 モデル化において、土台、枠材、胴差、パネル芯材等を置換したフ レーム材要素、壁パネル合板、床合板等を置換した長方形双一次要 素、緊結ボルト、アンカーボルト等を置換したバネ要素を用いた。 また、鈶直荷重については自重及び固定荷重を想定して設定した。

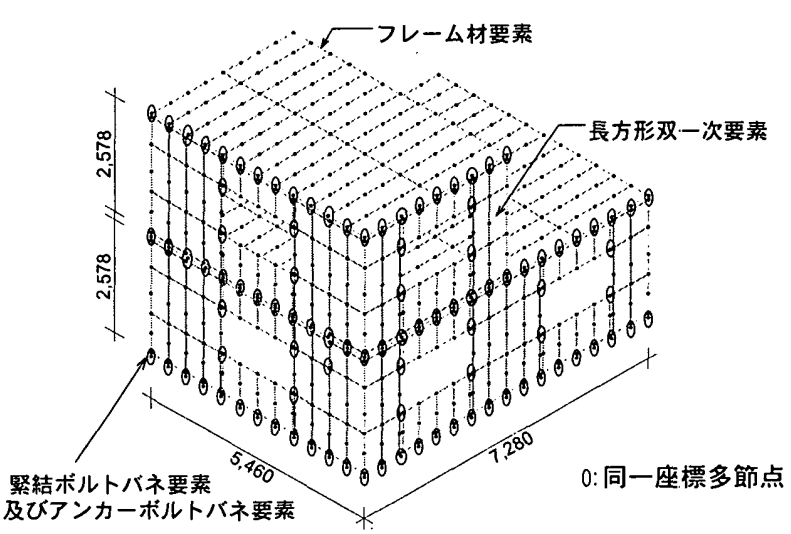

図 7 解析モデル

\section{2 解析方法}

解析方法は荷重增分法とし、各要素の変位量 (バネ要素) 及び応 力度 (面材要素) により剛性を変化させた弾塑性解析を用いた。

\section{3 入カデータ}

解析で用いた材料定数を表 7 に示す。材料定数は、部材実験及 び「木質構造設計基準・同解説 ${ }^{18)} 」 の$ 值を参考にして決:定した。め り込みバネ要素の剛性は柱の土台へのめり込みの初期剛性を求め る計算式 ${ }^{12)}$ を参考した。但し、実験で、パネル芯材が壁の回転に より局部的にめり込みが集中していることから、初期剛性算定式 に $1 / 2$ を乗じた。 
表 7 入力データ

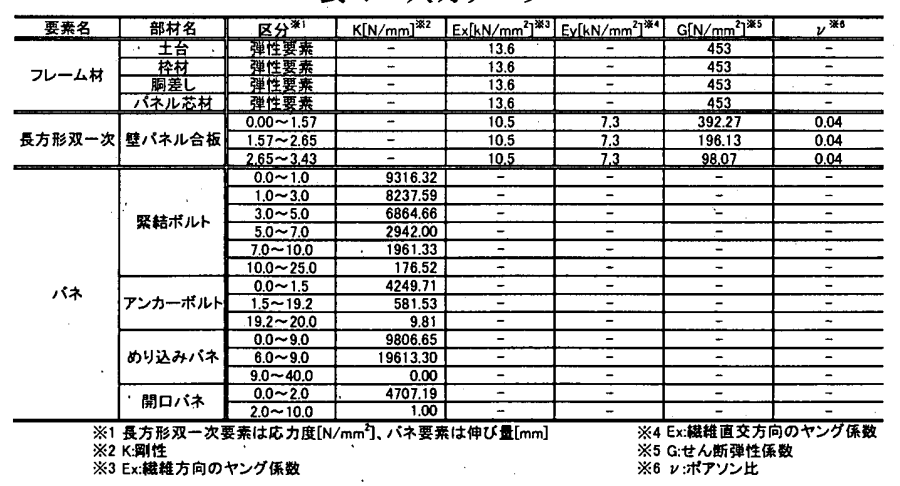

\section{4 実験結果と解析結果の比較・検討}

実験值と解析値をフェーズ・4 試験体の 2 方向加力での「荷重層間変形角関係」及び「変形挙動」について比較・検討する。

\subsection{1荷重-層間変形角関係}

図 8 に 8 通りにおける各層の荷重-層間変形角関係を示す。図 8 より、実験值と解析值とがよく一致しているのが確認された。
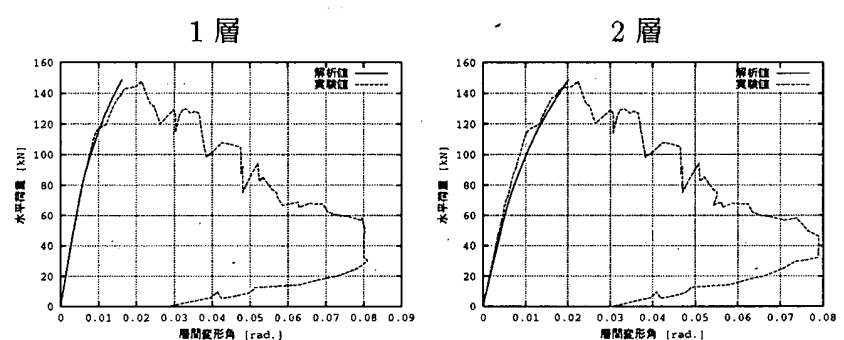

図 8 荷重-層間変形角関係:X8 通り

\subsection{2 変形挙動}

図 9 に 8 通りにおける層間変形角が $1 / 200[\mathrm{rad}$.$] 時の変形図$ を示す。実際の変形は微少であり、比較が困難なため変形を 20 倍 にして示す。

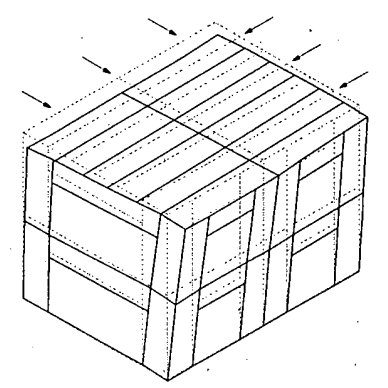

実験結果

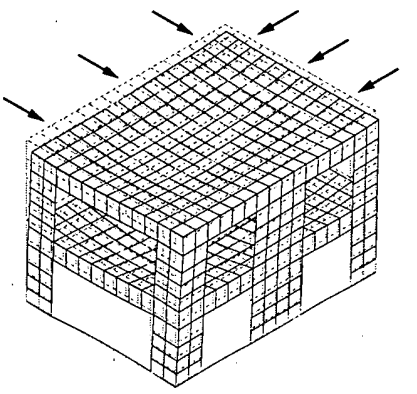

解析結果

図 9 変形挙動 (変形量 20 倍)

\subsection{3 本解析方法の有効性}

本解析は、初期から中期剛性までは非常に良く挙動を再現でき ている。最大荷重時の変形性状は若干の差異が見られた。今後の 課題としては最大荷重時のローリングシヤー破壊モードの導入及 び最大荷重時以降の解析表現が挙げられるが、本研究目的に挙げ る立体建物の「立体効果」、「斜めにより水平力を受けた時の挙動」 を検討する為には有効な手段であると言えよう。

\section{5 考察及び検討}

\section{1 立体効果}

本研究における立体効果とは、図 10 に示すように立体建物（3 次元）の荷重-変位関係と、立体建物（3 次元）の変形とその時の 耐力壁単体（2次元）のせん断耐力を用いて算出された荷重-変位 関係との違いとしている。立体効果が小さいと 2 次元のデータで 立体建物を評価できており、逆に大きいと評価できていない(構造 計算にプラス $\alpha$ の余裕がある) ということになる。本研究で定義し た立体効果が、偏心率、床構面のせん断弾性係数を変化させると どのような性状を示すのかを検討し、立体建物の水平せん断耐力 および変形性状の評価方法について提案を行いたい。
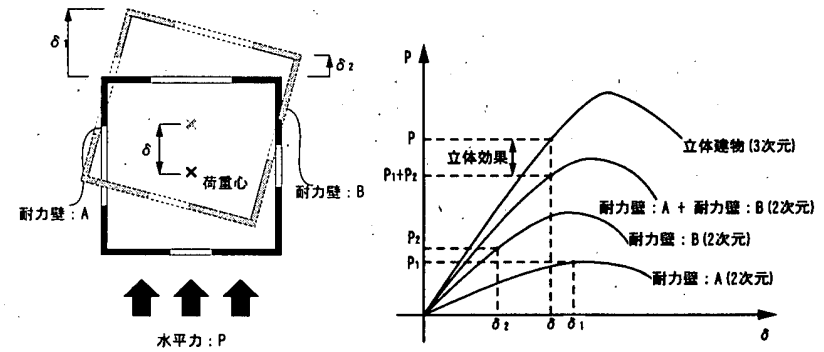

図 10 立体効果の考え方

\subsection{1 偏心率の違いが立体効果に及ほす影響 (実験結果の検証)}

偏心率の違いが立体効果に及ぼす影響について検証する。表 8 に偏心率と立体効果の関係を示す。また、フェーズ・4、2 方向同 時加力により破壊に至るまで行った結果を図 11 及び図 12 に示す。

表 8 偏心率と立体効果の関係 $[\mathrm{kN}]$

\begin{tabular}{|c|c|c|c|c|c|}
\hline & & X万同 & 立体建物 & 是し合わせ (面力壁) & 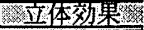 \\
\hline & & T1/960lrad. & 47.6 & 43.9 & 8 \\
\hline ᄀ & & 1/750 Lrad. & 58.6 & 56. & 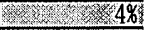 \\
\hline I & 0.00 & 1/600 Lrad. & 73.4 & 68.8 & 等 \\
\hline 1 & & 1/450 rad. & 94.6 & 90.0 & 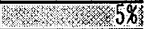 \\
\hline ズ & & Y方问 & 立体建物 & 是し合わせ (耐力壁) & 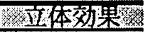 \\
\hline - & & 1/960 [rad. & 40.6 & 39.2 & 4 \\
\hline 2 & & 1/750 lrad. & 50.8 & 47.4 & \% \\
\hline & 0.00 & $1 / 600$ [rad. & 62. & 56.4 & 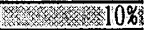 \\
\hline & & 1/450lrad. & 81.1 & 71.4 & 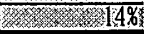 \\
\hline & & X万可 & 立体建物 & [足し合わせ (耐力壁) & 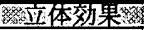 \\
\hline & & T1/960lrad. & 47.4 & 43.9 & 原为 \\
\hline フ & $\operatorname{Rex}$ & 1/750 Lrad. & 59.5 & $56:$ & 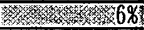 \\
\hline I & 0.00 & 1/600 lrad. & 73.0 & 69.4 & 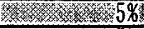 \\
\hline 1 & & 1/450lrad. & 94.6 & 90. & 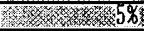 \\
\hline ズ & & 方司 & 立体建物 & 足し合わせ (耐力壁) & 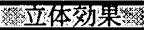 \\
\hline - & & 1/960lrad. & 30.3 & 26.7 & 留- \\
\hline 3 & Rey & 1/750 Lrad. & 37.0 & 32.4 & E \\
\hline & 0.38 & 17600lrad. & 44.6 & 38.5 & $16 \%$ \\
\hline & & 1/450 Irad. & 49.9 & 43.4 & 15 \\
\hline & & X方问 & 立体建物 & (耐力壁) & 烈泣体効果 \\
\hline & & 1/960/rad. & 41.1 & 37.1 & 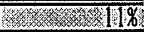 \\
\hline ᄀᄀ & $\operatorname{Rex}$ & 1/750 Lrad. & 51.5 & 46.7 & 20\% \\
\hline & 0.18 & $1 / 600$ lrad. & 62.8 & 55.7 & 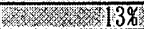 \\
\hline I & & 1/450 Irad. & 81.4 & 72.7 & Y \\
\hline ズ & & 方同 & 立体建物. & 今わせ (耐力壁) & 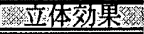 \\
\hline${ }^{\circ}$ & & 1/960 Lrad. & 27.6 & 26.8 & 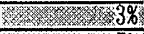 \\
\hline 4 & Rey & 1/750 rad. & 34.4 & 32.2 & 留 \\
\hline & 0.41 & $1 / 600$ [rad. & 42.4 & 38.6 & 10\% \\
\hline & & 1/450Lrad. & 46.4 & 41.8 & 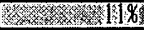 \\
\hline
\end{tabular}

表 8 より、立体効果はフェーズ・2(無偏心) では 4 $14 \%$ 、フェー ズ・3(片偏心) では X 方向で 5 8\%、Y 方向で 14〜16\%、フェー ズ・4(両偏心) では X 方向で 10〜 13\%、Y 方向で 3〜 $11 \%$ となっ 

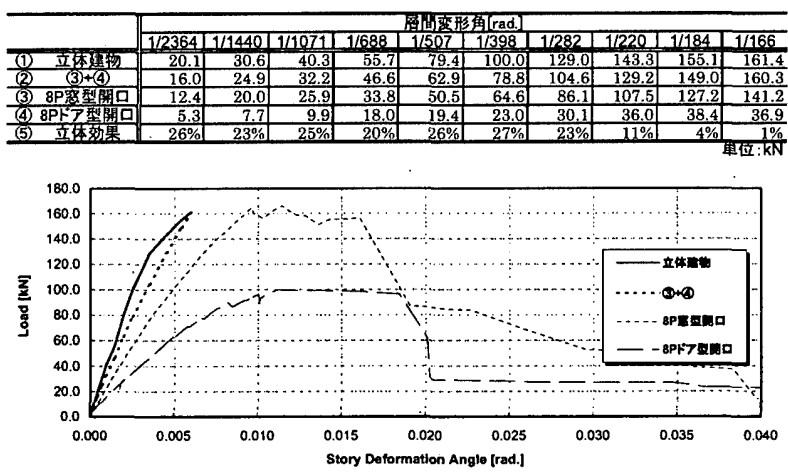

図 11 立体建物と足し合わせ（耐力壁）の相関性 （両偏心 : 2 方向加力 : 荷重心の X 方向変形角）
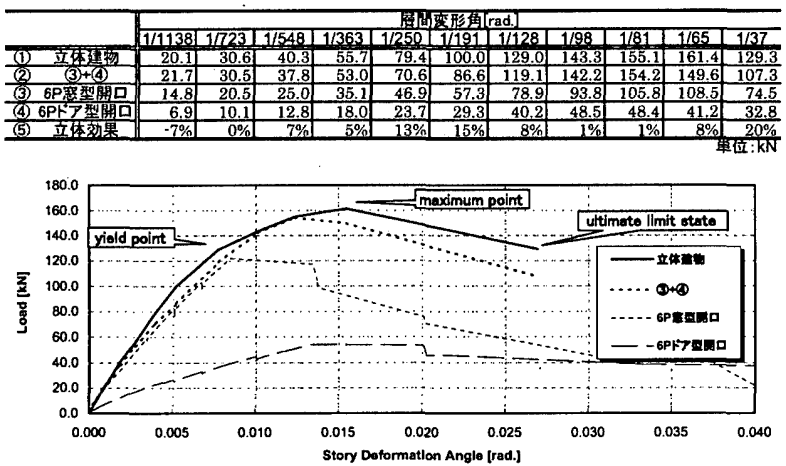

図 12 立体建物と足し合わせ（耐力壁）の相関性 （両偏心 : 2 方向加力 : 荷重心の Y 方向変形角）

た。偏心率が大きいと立体効果も大きくなり、偏心率が小さいと立 体効果も小さくなる傾向にある。これは偏心率が大きいと直交壁及 び床構面がねじれを抑制する効果が大きくなる為だと考えられる。

図 11 及び図 12 の荷重-層間変形角関係を見ると立体建物 (3 次 元) の場合と、耐力壁の足し合わせ (2 次元) では立体効果におい て最大 $20 \%$ の違いが見受けられるが、立体建物の構造計算を行う 上では、耐力壁の足し合わせ (2 次元) は、立体建物 (3 次元) を充 分再現できると考えられる。

\subsection{2 脚部のバネ剛性の逞いが立体効果に及ほす影響 (解析結果 の検証)}

ここでは、2 層立体建物の解析モデルにおける脚部 (緊結ボルト) のバネ剛性を $1.9[\mathrm{kN} / \mathrm{mm}](\phi 18$ 相当の $1 / 10) 、 9.3[\mathrm{kN} / \mathrm{mm}](\phi$ 18 相当の $1 / 2) 、 18.6[\mathrm{kN} / \mathrm{mm}](\phi 18$ 相当) と変化させたモデル 解析デー夕を用いて脚部のバネ剛性が立体効果に及ぼす影響につ いての検証を行う。表 9 に脚部のバネ剛性と立体効果の関係を示 す。表 9 より、立体効果は脚部のバネ剛性が緊結ボルト径 $\phi 18$ 相 当の $1 / 10$ のタイプで $8 \sim 19[\%] 、 \phi 18$ 相当の $1 / 2$ で $2 \sim 11[\%]$ 、 $\phi 18$ 相当のタイプで 1 8[\%] と脚部のバネ剛性が小さいと立体 効果は大きくなり、脚部のバネ剛性が大きいと立体効果は小さくな る傾向にある。

これは、脚部 (緊結ボルト) のバネ剛性が小さいと立体建物にお いて脚部の回転に占める直交壁のアンカーボルトの抵抗が占める 割合が大きくなり、直交壁の壁脚部反力を考慮しない「耐力壁の足 し合わせ (2 次元)」と比較すると、立体効果は大きくなると考え られる。脚部 (緊結ボルト) のバネ剛性が大きい場合は、脚部の変
形は緊結ボルトがほとんど抵抗するため、直交壁の壁脚部反力を 考慮しない「耐力壁の足し合わせ (2 次元)」と比較してま、立体効 果はほとんど現れていないと考えられる。

表 9 脚部の剛性と立体効果の関係 [\%](層間変形角 1/750[rad.] 時)

\begin{tabular}{|c|c|c|c|c|c|}
\hline \multirow{2}{*}{\multicolumn{2}{|c|}{ 試験体 }} & \multirow{2}{*}{ 床剛性 $\left[\mathrm{N} / \mathrm{mm}^{2}\right]$} & \multicolumn{3}{|c|}{ 脚部バネ剛性 } \\
\hline & & & $1 / 10$ & $1 / 2$ & $1 / 1$ \\
\hline \multirow{8}{*}{ フェーズ・2 } & \multirow{4}{*}{$\begin{array}{l}\mathrm{X} \\
\text { 方 } \\
\text { 向 }\end{array}$} & 49.03 & $\overline{16}$ & 11 & 9 \\
\hline & & 147.10 & 16 & 11 & 9 \\
\hline & & 392.27 & 16 & 11 & 9 \\
\hline & & 1176.80 & 16 & 11 & 9 \\
\hline & \multirow{4}{*}{$\begin{array}{l}Y \\
\text { 方 } \\
\text { 向 }\end{array}$} & 49.03 & 30 & 20 & 16 \\
\hline & & 147.10 & 30 & 20 & 16 \\
\hline & & 392.27 & 30 & 20 & 16 \\
\hline & & 1176.80 & 30 & 20 & 16 \\
\hline \multirow{8}{*}{ フェーズ・3 } & \multirow{4}{*}{$\begin{array}{l}\mathrm{X} \\
\text { 方 } \\
\text { 向 }\end{array}$} & 49.03 & 15 & 10 & 8 \\
\hline & & 147.10 & 15 & 10 & 8 \\
\hline & & 392.27 & 15 & 10 & 8 \\
\hline & & 1176.80 & 15 & 10 & 8 \\
\hline & \multirow{4}{*}{$\begin{array}{l}Y \\
\text { 方 } \\
\text { 向 }\end{array}$} & 49.03 & 37 & 27 & 23 \\
\hline & & 147.10 & 36 & 26 & 22 \\
\hline & & 392.27 & 35 & 25 & 21 \\
\hline & & 1176.80 & 35 & 25 & 21 \\
\hline \multirow{8}{*}{ フェーズ・ 4} & \multirow{4}{*}{$\begin{array}{l}X \\
\text { 方 } \\
\text { 向 }\end{array}$} & 49.03 & 13 & 9 & 7 \\
\hline & & 147.10 & 13 & 9 & 7 \\
\hline & & 392.27 & 13 & 9 & 7 \\
\hline & & 1176.80 & 13 & 9 & 7 \\
\hline & \multirow{4}{*}{$\begin{array}{l}Y \\
\text { 方 } \\
\text { 向 }\end{array}$} & 49.03 & 36 & 26 & 22 \\
\hline & & 147.10 & 36 & 26 & 21 \\
\hline & & 392.27 & 35 & 25 & 21 \\
\hline & & 1176.80 & 35 & 25 & 21 \\
\hline
\end{tabular}

\section{2 立体建物におけるせん断耐力及び変形の評価}

「5.1 立体効果」における検証により、偏心率及び床㴊性の変化 により立体効果は変化するものの実験値においては最大: $16 \%$ 、解 析值においては最大 $11 \%$ 程度という結果であり、立体建物 (3 次 元) の荷重-層間変形角関係は立体建物 (3 次元) の変形佂考慮した 耐力壁 (2 次元) の足し合わせにより充分再現できると考えられる。

\section{3 建物に斜めに水平力を受ける場合 (2 方向加力) (検討 5.3.1 水平荷重と各構面の層間変形角との関係}

表 10 に X 方向加力と $Y$ 方向加力の足し合わせに対する 2 方向 加力の層間変形角の割合 (実験值及び解析值 : 水平荷重 $40 \mathrm{kN}$ 時) を示す。実験值、解析值共に偏心率の違いにより、若干の差異（実 験値においては $1 \sim 2$ 割程度小さい、解析值においては $0.1 \sim 0.7$ 割 程度）が見られたものの、整合性が取れていると思われる。また、 有限要素法解析により床構面のせん断弾性係数を $\left(49.03\left[\mathrm{~N} / \mathrm{mm}^{2}\right]\right.$ 〜 1177.80[N/ $\left.\left.\mathrm{mm}^{2}\right]\right)$ と変化させたが、床構面のせん断弾性係数が 層間変形角の割合に与える影響は見受けられない。よって建物に斜 めに水平力を受ける場合に、X 方向 $\mathrm{Y}$ 方向の足し合わ比により の性状を再現できると考えられる。

\subsection{2 床構面における変形図}

図 13 に 2 方向同時加力及び X 方向加力と $Y$ 方向加力の足し合 わせの 2 階床構面及び $\mathrm{R}$ 階床構面の変形図 (実験值及び解析值 : 水平荷重 $40 \mathrm{kN}$ ) をフェーズ・4 試験体について示す。(見やすくす る為に変形を 10 倍としている。) X 方向、Y 方向の足し合わせの 変形と 2 方向同時加力における変形は似通った性状を示した。 
表 10 足しあわせに対する 2 方向加力の層間変形角の割合 [\%]

\begin{tabular}{|c|c|c|c|c|c|c|c|}
\hline & \multirow{2}{*}{ 層 } & \multirow{2}{*}{ 実験値 } & \multicolumn{4}{|c|}{ 解析值 (休岡U性: $\mathrm{N} / \mathrm{mm} 2)$} \\
\hline & & & & 49.03 & 147.10 & 392.27 & 1177.80 \\
\hline \multirow{8}{*}{ フェーズ・1 } & \multirow{2}{*}{$X_{0}$} & 2層 & 92.6 & - & $=$ & $=$ & - \\
\hline & & 1痛 & \begin{tabular}{|l|}
93.7 \\
\end{tabular} & - & - & - & - \\
\hline & \multirow{2}{*}{$x 8$} & 2層 & 88.4 & - & - & - & - \\
\hline & & 1層 & 83.5 & - & - & - & - \\
\hline & \multirow{2}{*}{ YO } & 2層 & 70.4 & - & - & - & - \\
\hline & & 1層 & 65.2 & - & - & - & - \\
\hline & \multirow{2}{*}{ Y6 } & 2層 & 79.8 & - & - & - & - \\
\hline & & 1層 & 84.4 & - & - & - & - \\
\hline \multirow{8}{*}{ フェーズ・2 } & \multirow{2}{*}{ X0 } & 2層 & 86.3 & 101.3 & 101.3 & 101.4 & 101.4 \\
\hline & & 1層 & 83.1 & 100.4 & 100.5 & 100.5 & 100.5 \\
\hline & \multirow{2}{*}{$x 8$} & 2層 & 82.7 & 102.1 & 101.9 & 101.8 & 101.7 \\
\hline & & .1層 & 86.6 & 101.1 & 101.1 & 101.1 & 101.1 \\
\hline & \multirow{2}{*}{ Y0 } & 2層 & 86.9 & 102.3 & 102.4 & 102.4 & 102.4 \\
\hline & & 1層 & 86.6 & 102.0 & 102.1 & 102.1 & 102.1 \\
\hline & \multirow{2}{*}{ Y6 } & 2層 & 92.2 & 102.9 & 102.7 & 102.6 & 102.4 \\
\hline & & 1層 & 92.3 & 101.3 & 101.3 & 101.3 & 101.3 \\
\hline \multirow{8}{*}{ フェーズ・3 } & \multirow{2}{*}{ X0 } & 2層 & 90.9 & 102.2 & 102.3 & 102.2 & 102.2 \\
\hline & & 1層 & 89.5 & 101.4 & 101.5 & 101.2 & 101.3 \\
\hline & \multirow{2}{*}{$X 8$} & 2層 & 91.2 & 102.1 & 101.8 & 101.6 & 101.4 \\
\hline & & 層 & 96.1 & 101.4 & 101.3 & 101.2 & 101.2 \\
\hline & \multirow{2}{*}{ Y0 } & 2層 & 83.9 & 95.9 & 96.6 & 97.0 & 97.3 \\
\hline & & 1層 & 94.6 & 98.7 & 98.7 & 98.9 & 98.8 \\
\hline & \multirow{2}{*}{ Y6 } & 2層 & 81.1 & 96.8 & 96.2 & 95.8 & 95.5 \\
\hline & & 1層 & 75.4 & 96.7 & 95.8 & 95.8 & 95.7 \\
\hline \multirow{8}{*}{ フェーズ・4 } & \multirow{2}{*}{$\mathrm{X} 0$} & 2厦 & 93.3 & 101.6 & 101.9 & 102.1 & 102.1 \\
\hline & & 層 & 89.0 & 100.5 & 100.6 & 100.5 & 100.5 \\
\hline & \multirow{2}{*}{$\mathrm{X} 8$} & 2層 & 95.8 & 103.2 & 103.1 & 102.9 & 102.8 \\
\hline & & 層 & 101.5 & 101.8 & 101.7 & 101.8 & 102.0 \\
\hline & \multirow{2}{*}{ Y0 } & 2層 & 86.4 & 96.1 & 96.6 & 97.0 & 97.2 \\
\hline & & 層 & 92.6 & 98.3 & 98.2 & 98.0 & 97.9 \\
\hline & \multirow{2}{*}{ Y6 } & 2層 & 88.5 & 96.9 & 95.8 & 94.9 & 94.4 \\
\hline & & 1層 & 78.6 & 94.8 & 93.9 & 93.6 & 93.6 \\
\hline
\end{tabular}

\section{実験值}
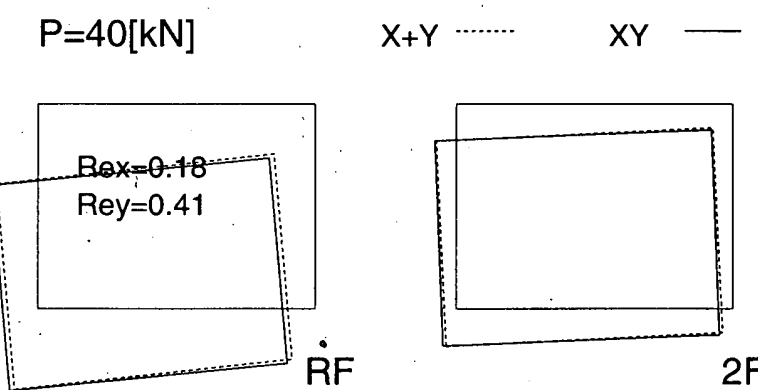

解析値

$\mathrm{P}=40[\mathrm{kN}]$

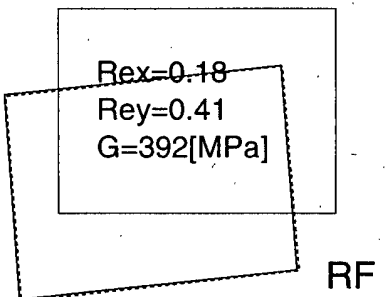

フェーズ・4(両偏心)

図 13 床構面の変形図 (変形量 10 倍)

\subsection{3 脚部の引き抜きカ}

表 11 に 2 方向加力に対する X 方向加力と Y 方向加力の足し合 わせの引き抜き力の割合 (実験値及び解析值 : 水平荷重 $40 \mathrm{kN}$ ) を 示す。また、現行の構造計算方法の検証として実験值及び解析値を 用いて、 $\mathrm{X}$ 方向と $\mathrm{Y}$ 方向で水平力が $40 \mathrm{kN}$ として独立検討した引 き抜き力と斜め $45^{\circ}$ 方向に水平力が $40 \mathrm{kN}$ 相当とした 2 方向加力
$(1 / \sqrt{2}$ 倍) との比較を表 12 に示す。表中の網掛けは各試験体にお いて引き抜き力が最大を示した箅所を示す。これによると、X 方 向、Y方向の引き抜け力よりも斜めの外力の方が厳しくなる場合 があり注意が必要である。

表 112 方向加力の足しあわせに対する引き抜き力の割合

\begin{tabular}{|c|c|c|c|c|c|c|}
\hline & \multirow{2}{*}{ 実験値 } & \multicolumn{4}{|c|}{ 解析値 (本剛性: $\mathrm{N} / \mathrm{m} m 2$ ) } \\
\hline & & & 49.03 & 147.10 & 392.27 & 1177.80 \\
\hline \multirow{3}{*}{ フェーズ・1 } & (1)足し合わせ $[\mathrm{kN}]$ & 24.33 & & $=$ & - & 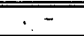 \\
\hline & (2)2方向加力 [kN] & 21.40 & - & - & - & - \\
\hline & (2)/(1) $[\not]$ & 87.96 & - & - & - & - \\
\hline \multirow{3}{*}{ フェーズ・2 } & (1)足し合わせ $[\mathrm{kN}]$ & 19.32 & 17.34 & 17.34 & 17.35 & 17.34 \\
\hline & \begin{tabular}{|l} 
(2)2方向加力 $[\mathrm{kN}]$ \\
\end{tabular} & 18.30 & $22: 17$ & 22.19 & 22.20 & 22.21 \\
\hline & (2) $/(1)[\not]$ & 94.72 & 127.84 & 127.96 & 128.00 & 128.07 \\
\hline \multirow{3}{*}{ フェーズ・3 } & (1)足し合わせ $[\mathrm{kN}]$ & 22.69 & 23.52 & 25.11 & 25.99 & 26.36 \\
\hline & 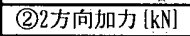 & 21.57 & 28.16 & 29.77 & 30.56 & 30.95 \\
\hline & (2)/(1) $[\%]$ & 95.06 & 119.74 & 118.56 & 117.60 & 117.45 \\
\hline \multirow{3}{*}{ フェーズ・4 } & (1)足し合わせ $[\mathrm{kN}]$ & 23.90 & 25.17 & 27.00 & 27.86 & 28.27 \\
\hline & (2)2方向加力 $[\mathrm{kN}]$ & 24.02 & 29.66 & 31.49 & 32.36 & 32.77 \\
\hline & (2)/(1) [\%] & 100.50 & 117.83 & 116.62 & 116.14 & 115.90 \\
\hline
\end{tabular}

表 121 方向加力と 2 方向加力の引き抜き力における相関性

\begin{tabular}{|c|c|c|c|c|c|c|}
\hline \multirow{2}{*}{ 試験体 } & \multirow{2}{*}{ 検討方向 } & \multirow{2}{*}{ 実験値 } & \multicolumn{4}{|c|}{ 解析値 (休剛性: $/ \mathrm{m} / \mathrm{m} 2$ ) } \\
\hline & & & 49.03 & 147.10 & 392.27 & 1177.80 \\
\hline \multirow{3}{*}{ フェーズ・ } & X方向 & 10.60 & - & - & - & - \\
\hline & Y方向 & 13.73 & - & - & - & - \\
\hline & 斜め $45^{\circ}$ 方向 & 14.70 & - & - & - & - \\
\hline \multirow{3}{*}{ フェーズ・ } & X方向 & 7.62 & 6.72 & 6.71 & 6.72 & 6.72 \\
\hline & Y方向 & 11.70 & 10.62 & 10.63 & 10.63 & 10.62 \\
\hline & 斜め $45^{\circ}$ 方向 & 13.06 & 14.07 & Q14.08 & 14. 09 & 14. 10 \\
\hline \multirow{3}{*}{ フェーズ・ } & X方向 & 6.63 & 7.04 & 7.04 & 7.05 & 7.05 \\
\hline & Y方向 & 16.06 & 16.48 & 18.07 & 18.94 & 19.30 \\
\hline & 斜め $45^{\circ}$ 方向 & 14.61 & 1831 & 19.43 & 19.99 & 20.27 \\
\hline \multirow{3}{*}{ フェーズ・ } & X方向 & 7.45 & 8.94 & 9.41 & 9.64 & 9.76 \\
\hline & Y方向 & 16.45 & 16.23 & 17.58 & 18.22 & 18.52 \\
\hline & 斜め $45^{\circ}$ 方向 & 16.82 & 19.36 & 20.65 & 21.26 & 21.55 \\
\hline
\end{tabular}

2F 6 まとめ

\section{1 立体建物におけるせん断耐力及び変形の評価，}

荷重-層間変形角関係において立体建物 (3 次元) と、耐力壁の足 し合わせ (2 次元) では立体効果において最大 $20 \%$ 違いが見受け られるが、立体建物の構造計算を行う上では、立体建物 (3 次元) の変形を考慮した耐力壁 (2 次元) の足し合わせにより立体建物 $(3$ 次元) を充分再現できると考えられる。

\section{2 立体効果}

・偏心率においては、若干ではあるが偏心率が大きい方が立体効果 が大きい。

$2 \mathrm{~F}$

・立体効果に及ぼす床剛性の影響はほとんど無い。

・立体効果に及ぼす影響が最も大きい因子は脚部接合部の剛性であ る。(直交壁の壁脚部反力及び変形が立体建物 (3 次元) の水平変位 に大きく影響していると考えられる。)

\section{3 建物に斜めに水平力を受ける場合 (2 方向加力) の検討}

水平力に対する耐力壁のせん断力の検討等においては、X 方向 Y 方向それぞれの検討を行えばよい。

水平力に対する耐力壁脚部の検討は斜めからの水平力を受ける 場合を X 方向 Y 方向の足し合わせで表現できることを実大建物に 
おける実験及び有限要素法を用いた解析で確認できた。また、水 平力に対する脚部接合部の引き抜き力の検討においては $\mathrm{X}, \mathrm{Y}$ 方向 より斜めの外力の方が厳しくなる場合があり、注意が必要である。 (木質パネル構法においては出隅の緊結ボルト及びアンカーボルト が X 方向, $\mathrm{Y}$ 方向の 2 方向に期待している為)

なお、本研究の一部は、平成 10 年 14 年度の文部省学術フロ ンティア推進事業の重点研究費 :「激震動を受ける建築構造物及び 機器・装置の耐震性能の向上化」(研究代表者 : 洪忠喜) 及び平成 12 年度よりの文部科学省科学研究費補助金 (基盤研究 A)：「直下 地震に対する部材、架構の耐震性能向上に関する研究」(研究代表 者 : 野口弘行)によった。

\section{謝辞}

本研究の実験実施にあたり、小林幹大氏・富居勝宏氏・渦波 きさら氏・福間崇博氏・1999 年度の卒業研究生諸氏・及びミサワ ホーム 技術部所員の方々には多大なご協力を得た。また、本論文 をまとめるにあたり、小川春彦氏にご協力を頂いた。ここに記して 謝意を表する。

\section{参考文献}

1) 杉山英男:建築構造学大系 22 木構造, 株式会社 彰国社, 1971

2）杉山英男，松本忠史 : Empirical Equations for Estimation of Racking Strength of a Plywood-Sheathed Shear Wall with Openings, 日本 建築学会大会学術講演梗概集,pp.89 90,1994.9

3）秋山真一，村上雅英：立体効果を考慮した据れ変形の簡易評価モデル，日本 建築学会大会学術講演梗概集,pp.203〜204,1997.9
4) 野口弘行, 暒川久光, 富居勝宏, 平田俊次 : 実大 2 階建木質パ汸ル住宅の 2 方向加力実験に関する研究〜その 1・研究目的及び実験概要〜，日本建築学 会大会学術講演梗概集,pp.185 186,2000.9

5) 富居勝宏，野口弘行，楃川久光，中尾行宏：実大 2 階建木質パ视儿住宅の 2 方向加力実験に関する研究〜その 2 - 現設計法との比較 - 検討〜, 日本建築 学会大会学術講演梗概集,pp.187〜 188,2000.9

6) 暒川久光, 野口弘行, 壱岐俊英 : 実大 2 階建木質パネル住宅の 2 方向加力実 験に関する研究〜その $3 \cdot 2$ 方向火力による影響について〜, 日本建築学会 大会学術講演梗概集,pp.189〜 190,2000.9

7) 神谷文夫, 杉本健一, 三井信宏, 平田俊次, 壱岐俊英, 棍川久光 : 面材接着耐 力壁のせん断耐力に及ほす壁長さ，壁高さ，開口率の影響，日㶱建築学会大 会学術講演梗概集,pp.387〜388,2001.9

8）福間崇博，本岡淳一，梶川久光，富居勝宏，平田俊次，野口弘行：木質立体建 物のねじれ挙動に関する研究〜その 1 ・耐力壁せん断実娩及で解析検証〜， 日本建築学会大会学術講演梗概集,pp.225 226,2001.9

9）富居勝宏, 暒川久光, 野口弘行 : 木質立体建物のねじれ挙動に関する研究〜 その $2 \cdot$ 立体効果について (実験的検証) , 日本建築学会大会学術講演梗概 集,pp.227〜228,2001.9

10）梶川久光，富居勝宏，野口弘行：木質立体建物のねじれ挙動に関する研究〜 その 3・床剛性を考慮したねじれ挙動について〜，日本建築学会大会学術劃 演梗概集,pp.229 230,2001.9

11）福間崇博，梶川久光, 野口弘行 : 木質接着パネル構法による開口を有する耐 力壁のせん断挙動に関する研究, 日本建築学会大会学術講演梗概集,pp.323 $\sim 324,2002.8$

12) 稲山正弘:木材のめり込み理論とその応用-勒性を期待したラーメン接合部の 耐震設計法に関する研究-，東京大学工学部坂本松村研究室 1991 年学位論 文, 1991.12

13）日本建築学会 (編): 建築耐震設計における保有耐力と変形性能 (1990),1990

14）木質構造研究会 (編)：木質構造建築読本,1994

15）日本建築学会 (編): 木質構造設計ノート,1995

16）杉山英男 : 木質構造 第 3 版,2001

17）菊池重昭：建築学構造シリーズ 建築木質構造,2001

18）日本建築学会 (編)：木質構造設計規準・同解説, 2002

19）日本ツーバイフォー建築協会 : 2002 年 枠組壁工法建築物構造計算指針,2002

（2003年 5 月 9 日原稿受理，2004年 4 月 6 日採用決定） 